Transactions of the American Fisheries Society, 1998, v.127, n.1, p.70-83.

ISSN: (Print 0002-8487) (Online 1548-8659)

doi: 10.1577/1548-8659(1998)127<0070:LBAGSP>2.0.CO;2

http://www.fisheries.org

http://afsjournals.org/loi/fitr

http://afsjournals.org/doi/pdf/10.1577/1548-8659\%281998\%29127\%3C0070\%3ALBAGSP\%3E2.0.CO\%3B2

(C) Copyright by the American Fisheries Society 1998 


\title{
Linking Bluegill and Gizzard Shad Prey Assemblages to Growth of Age-0 Largemouth Bass in Reservoirs
}

\author{
James E. Garvey ${ }^{1}$ And Roy A. Stein ${ }^{2}$ \\ Aquatic Ecology Laboratory, Department of Zoology, The Ohio State University \\ 1314 Kinnear Road, Columbus, Ohio 43212, USA
}

\begin{abstract}
Either gizzard shad Dorosoma cepedianum or bluegills Lepomis macrochirus dominate prey assemblages in many small $(<100$ ha) Ohio reservoirs. Because gizzard shad spawn early in the spring and their offspring grow rapidly, age- 0 gizzard shad may be invulnerable to age- 0 largemouth bass Micropterus salmoides, thereby compromising this piscivore's growth and, potentially, recruitment. To test this hypothesis, we quantified growth, abundance, and diets of age0 largemouth bass in reservoirs dominated by age- 0 bluegills (one reservoir) or age- 0 gizzard shad (two reservoirs) during June through early October 1992-1994. In the bluegill-dominated reservoir, age-0 largemouth bass grew slowly (about $0.04 \mathrm{~g} / \mathrm{d}$ ) during June through mid-August. Though age-0 bluegills became abundant after mid-August, contributing to rapid growth (about $0.2 \mathrm{~g} / \mathrm{d}$ ) of age- 0 largemouth bass, these age- 0 largemouth bass only reached small to moderate sizes by fall (range of mean wet weights, 3-7 g). In the reservoirs dominated by gizzard shad, summer growth and fall sizes of largemouth bass varied among systems and years. During one summer in one shad-dominated reservoir, an early rise in temperature plus small age- 0 gizzard shad probably contributed to rapid growth $(\sim 0.12 \mathrm{~g} / \mathrm{d})$ and large fall size (mean wet weight, $10.8 \mathrm{~g})$ of age- 0 largemouth bass. More commonly, age-0 largemouth bass grew slowly or moderately ( $\sim 0.06 \mathrm{~g} / \mathrm{d})$. However, fall sizes of largemouth bass always were equivalent to or exceeded those in the bluegilldominated reservoir (range of mean wet weights, 3-11 g). Our results suggest that growth of age0 largemouth bass should vary more in systems dominated by gizzard shad than in bluegilldominated ones. Management efforts that increase gizzard shad vulnerability during early summer may reduce this variability, thereby enhancing first-summer growth and, potentially, recruitment success of largemouth bass.
\end{abstract}

Aquatic communities often contain organisms that, through biotic interactions such as predation, exert strong effects on species assemblages (Paine 1966; Carpenter et al. 1987; Power 1990; Mittelbach et al. 1995). These interactions can occur among adult life stages. More typically, for those organisms experiencing high mortality during early life (such as fishes), strongly interacting species influence growth and survival of early life stages, thereby dictating adult abundance and, hence, community structure.

In small, highly productive reservoirs ( $<100 \mathrm{ha})$ in North America, omnivorous gizzard shad Dorosoma cepedianum often are abundant (Grinstead et al. 1978; Ploskey and Jenkins 1982; Johnson et al. 1988) and, at multiple life stages, can regulate reservoir communities. As juveniles $(>25 \mathrm{~mm}$ in total length, TL), gizzard shad and a closely related species, threadfin shad Dorosoma petenense, often reduce zooplankton (Ziebell et al. 1986; Dettmers and Stein 1992, 1996; DeVries and Stein 1992), potentially compromising growth and survival of

\footnotetext{
1 Present address: Queen's University, Department of Biology, Kingston, Ontario K7L 3N6, Canada.

${ }^{2}$ Corresponding author: stein4@osu.edu
}

planktivorous larval fishes that simultaneously reside in the open water (Jenkins 1957; Kirk et al. 1986; Guest et al. 1990; DeVries et al. 1991; DeVries and Stein 1992; Stein et al. 1995; Dettmers and Stein 1996). In Ohio reservoirs, abundances of age-0 gizzard shad and sunfishes (primarily bluegills Lepomis macrochirus) are negatively related (DeVries and Stein 1992; Garvey et al. 1998), probably due to competitive interactions in concert with abiotic and biotic factors that reduce age-0 bluegill survival while improving gizzard shad success in reservoirs (Stein et al. 1995, 1996; Bremigan and Stein 1997; Garvey 1997).

Variability in abundances of age-0 bluegills and gizzard shad can influence growth of age-0 largemouth bass Micropterus salmoides, a dominant piscivore in many systems (Swingle and Smith 1940; Dillard and Novinger 1975; Storck 1986; Olson 1996). Though predators can modify prey communities through direct effects (i.e., removal of prey by consumption: Hrbacek et al. 1961; Brooks and Dodson 1965) and indirect effects (suppressing foraging by prey: Cerri and Fraser 1983), factors such as size structure (Mills et al. 1989; Bremigan and Stein 1994) and species composition (Noble 1975; Lemly and Dimmick 1982; Confer 
and Lake 1987) of prey assemblages can influence predator growth. Because age-0 gizzard shad typically grow rapidly, they often reach sizes exceeding gapes of age-0 largemouth bass, thus preventing consumption (Olmstead 1974; Noble 1981; Storck 1986; Hambright et al. 1991). Conversely, age-0 bluegills often remain vulnerable during early life, substantially enhancing growth of age-0 largemouth bass during their ontogenetic switch from macroinvertebrates to piscivory (Timmons et al. 1980; Keast and Eadie 1985; Bettoli et al. 1993; Olson 1996). Hence, in systems where gizzard shad are abundant and bluegills are rare, gape-limited, age-0 largemouth bass may grow slowly (DeVries et al. 1991; Stein et al. 1995; Garvey et al. 1998). In systems where gizzard shad are rare or absent and age- 0 bluegills are abundant, age-0 largemouth bass should switch to bluegills, grow rapidly, and reach large sizes by fall (DeVries et al., 1991; Stein et al. 1995; Garvey et al. 1998). Because greater fall size probably improves overwinter survival (Gutreuter and Anderson 1985; Miranda and Hubbard 1994a, 1994b; Ludsin and DeVries 1997), substantial differences in absolute growth of age- 0 largemouth bass by fall between reservoirs dominated by gizzard shad and those dominated by bluegills should translate to overwinter survival differences as well.

To explore complex factors that influence variable growth of age-0 largemouth bass in reservoirs dominated by gizzard shad or bluegills, we quantified growth, abundance, and diets of largemouth bass as a function of size structure and abundance of age- 0 prey fishes in three Ohio reservoirs during spring through fall 1992, 1993, and 1994. Through intensive sampling, we determined how growth of age-0 largemouth bass varied across systems containing different prey communities, inferring from these patterns their relative recruitment success.

\section{Methods}

Study reservoirs. - To quantify growth and diets of age-0 largemouth bass (henceforth, all fish are age- 0 unless otherwise specified) as well as prey fish dynamics in a system where littoral gizzard shad were absent, we sampled fishes in Hargus Lake (59 ha; Pickaway County, central Ohio), a moderately clear (mean annual secchi depth across 3 years, $1.5 \mathrm{~m}$ ), eutrophic reservoir with abundant littoral zone vegetation (often $100 \%$ cover consisting of mostly waterwillow Justicia americana and cattail Typha spp.). Though adult gizzard shad probably were stocked into Hargus Lake and, thus, were present during 1993 and 1994, age-0 gizzard shad were not abundant, apparently never surviving beyond the larval stage (Garvey et al. 1998; this study). To explore dynamics of littoral largemouth bass and prey fish in systems with abundant gizzard shad, we surveyed littoral fishes in Kokosing Lake (65 ha; Knox County, north central Ohio) and Stonelick Lake (69 ha; Clermont County, southern Ohio), two turbid reservoirs (mean annual secchi depths, 0.4 and $0.5 \mathrm{~m}$, respectively) where gizzard shad densities have been typically high each year (Bremigan et al. 1991; DeVries et al. 1991; Dettmers and Stein 1992; DeVries and Stein 1992; Garvey et al. 1998). In Kokosing Lake, inshore vegetation was usually absent; Stonelick Lake contained moderate abundances of emergent vegetation including Typha spp.

Sampling.-In each year during early June through early October, we quantified sizes and abundances of littoral fishes every 1-2 weeks by seining (9-m bag seine, 3-mm mesh) three fixed, 25-40-m inshore transects (one haul per transect), one each located near the downstream end, middle, and upstream end of each reservoir. For each seine haul, we identified all fishes, measured total lengths of at least 50 randomly chosen fish of each species, and counted unmeasured individuals. We also weighed (nearest $0.1 \mathrm{~g}$, wet weight) at least 10 largemouth bass per seine site, stratifying these measurements across the range of largemouth bass sizes within each sample. During all 3 years, we froze at least 10 fish per seine site for diet analysis. In Hargus Lake, seining efficiency for largemouth bass generally declined by late summer. Thus, in 1994, we sampled largemouth bass for size estimates by electrofishing areas near the three fixed seine sites on October 13 in this reservoir. For each date, weights of unweighed largemouth bass were estimated by using least-squares regression models (all significant, $P<0.05$; ranges of $r^{2}$ values, 0.92-0.99) derived from $\log _{e}(x)$-transformed lengths and weights of largemouth bass measured on the same date.

Temperature.-Because temperature strongly influences growth of largemouth bass (Niimi and Beamish 1974; Rice and Cochran 1984), we recorded temperatures at our downstream site (near the dam) on each sampling date during June through mid-September. To compare temperatures among systems and years, we used analysis of covariance (ANCOVA) with year and reservoir as main effects and sampling date as the concomitant variable (type III sum of squares; Neter et al. 1990). Means within significant main effects were 
compared with Scheffé's multiple-comparisons test (Neter et al. 1990).

Abundance of largemouth bass.-Relative abundance of largemouth bass across years and reservoirs (catch per unit effort, CPE) was standardized as the number of largemouth bass caught per meter of inshore seining transect. Within each year, we compared mean largemouth bass CPE during each sampling week (treating seine sites as fixed replicates within each reservoir) by using repeated measures analysis of variance (ANOVA), in which the main effect was reservoir (type III sum of squares; generalized linear model (GLM) procedure; SAS Institute 1983). If data for the three reservoirs did not fall into a common sampling week, we were unable to include them in the repeated measures ANOVA. We could not combine data across years to test for a year effect because reservoirs were sampled at different intervals during each year. Data for CPE were $\log _{e}(x+1)$ transformed before analyses because of the presence of extreme values.

Growth of largemouth bass.-During each year, growth rates $(\mathrm{g} / \mathrm{d})$ of largemouth bass for each reservoir were estimated as slopes of linear regressions of sampling date (independent variable) versus the dependent variable, largemouth bass weight (g wet weight; as per Olson 1996). Because we expected growth rates of largemouth bass to change substantially as the diet changed from macroinvertebrates to fish, we used a continuous twophase regression technique to determine if growth rates of largemouth bass changed significantly during each year (Nickerson et al. 1989; also see Olson 1996). This technique iteratively fitted regressions through the growth data before and after each observation on the time axis, finding the pair of regressions that produced the lowest combined residual sum of squares. By using $F$-tests, we determined whether these two-phase regressions for growth significantly reduced residual sum of squares relative to single linear regressions for each reservoir and year (Olson 1996). If two-phase regressions did not significantly improve regression model fits, we concluded that growth could be characterized by a single growth rate. After determining which regression model was appropriate, we tested the significance of each regression with an $F$-test (Nickerson et al. 1989; Neter et al. 1990). During each year, we compared growth rates (i.e., slopes) of largemouth bass between reservoirs during the first growth phase (generally before August 15) and, during the second growth phase, if applicable, with two-tailed $t$-tests for un- equal variances (Sokal and Rohlf 1981), in which we adjusted our type I error rate (Bonferroni-adjusted $\alpha, 0.025 / 15=0.002$ ) for all possible pairwise comparisons of reservoirs within years.

In addition to estimating growth rates, we compared sizes of largemouth bass between reservoirs at the end of each sampling season. By choosing dates when samples for reservoirs were robust and overlapped (September 15), we estimated sizes (grams wet weight) of largemouth bass with our regression models and adjusted variances (Neter et al. 1990). As with growth rates, we compared size estimates between reservoirs with two-tailed $t$-tests for unequal variances (Sokal and Rohlf 1981), in which we adjusted our type I error rate (Bonferroni adjusted $\alpha, 0.025 / 7=0.004$ ) for all possible pairwise comparisons of reservoirs within years. Though our regressions adequately characterized growth during the entire season, inspection of residuals indicated that these models often underestimated sizes of largemouth bass on the first sampling date of each year. To compare sizes of largemouth bass across reservoirs during early summer, we compared weights on the first sampling week in which largemouth bass in all three reservoirs were captured (1992: Hargus = July 23, Kokosing $=$ July 15, Stonelick = July 16; 1993: Hargus $=$ July 9, Kokosing $=$ July 8, Stonelick $=$ July 6; 1994: Hargus $=$ June 25, Kokosing $=$ June 27 , Stonelick $=$ June 28) with a two-factor ANOVA (type III sum of squares; main effects = reservoir, year). Pairwise comparisons of main effects means were conducted with a post-hoc Tukey's multiple-comparison test (SAS Institute 1983).

Abundance of prey fishes.-We estimated the availabilities of bluegills and gizzard shad, the most abundant prey fish in many Ohio reservoirs (Johnson et al. 1988; DeVries et al. 1991), to largemouth bass. By using known relationships between sizes of largemouth bass and their preferred sizes of gizzard shad and blugill prey (Timmons et al. 1980; Hoyle and Keast 1987; Michaletz 1997b), we assumed that largemouth bass generally consume lengths ( $\mathrm{mm}, \mathrm{TL}$ ) of bluegills and gizzard shad that are less than or equal to $33 \%$ and $50 \%$ of their TL, respectively. With these relationships, we then compared overlap of length of each largemouth bass with length distributions of available gizzard shad and bluegill prey within each seine haul on each date. We then calculated the mean number of bluegills and gizzard shad available (as number/m seine haul; CPE) for all largemouth bass at each seine site. As with largemouth bass abundance, we compared mean CPE for bluegills and 
gizzard shad each sampling week (treating seine sites as fixed replicates within each reservoir) by using repeated measures ANOVA in which the main effect again was reservoir (type III sum of squares; GLM procedure; SAS Institute 1983). As with our analysis of largemouth bass abundance, if data for the three reservoirs did not fall into a common sampling week, we were unable to include them in the repeated measures ANOVA. These CPE data were $\log _{e}(x+1)$ transformed before analysis.

Largemouth bass diets.-Characterizing diets of largemouth bass provides quantitative insight into patterns of prey use and, ultimately, of growth. To quantify diets, stomachs of largemouth bass were removed, all taxa were identified to Family when possible, and total biomass (wet weight, $\mathrm{mg}$ ) was estimated by using body dimension-weight relationships to calculate individual item weights (for macroinvertebrates: Smock 1980; G. G. Mittelbach, Kellogg Biological Station, Michigan State University, unpublished data; zooplankton: Dumont et al. 1975; Culver et al. 1985; prey fish: Wahl and Stein 1991). For each item, we measured the appropriate body dimensions (e.g., head depth, body length; measurements ranged $0.05-1.5 \mathrm{~mm}$ ) required for each regression by using a dissecting microscope at $25 \times$ power with digitizing equipment (SigmaScan 1992). We then converted each measurement to wet weight (see Garvey et al. 1998). If mostly digested, fish in diets often were identified from vertebral counts, which were unique to each species (Holland-Bartels et al. 1990). For each date, we then explored general dietary patterns of largemouth bass by pooling dietary items into three categories: zooplankton, macroinvertebrates, and fish. First, we calculated relative proportions (by wet weight, $\mathrm{mg}$ ) of each category within each largemouth bass and then averaged these proportions across all largemouth bass within each reservoir and date.

\section{Results}

\section{Temperature Differences}

Within years, temperatures did not differ among reservoirs and did not vary with sampling date (Figure 1; ANCOVA: reservoir and date, $P>$ 0.05). However, temperatures differed among years (Figure 1; ANCOVA: year, $F=7.5$, df $=$ 2, 91, $P<0.05) ; 1993$ and 1994 temperatures were, on average, $2.6^{\circ} \mathrm{C}$ and $1.8^{\circ} \mathrm{C}$ warmer, respectively, than 1992 temperatures (Figure 1; Scheffé's multiple comparison: $P<0.05)$. Tem- peratures did not differ between 1993 and 1994 (Figure 1; Scheffé's multiple comparison: $P>$ $0.05)$.

\section{Abundance of Largemouth Bass}

During 1992 and 1994, relative CPE of largemouth bass did not differ among reservoirs through time (Figure 2; repeated measures ANOVA: 1992 and 1994, both reservoir and time, $P>$ 0.05). Conversely, during 1993, CPE of largemouth bass differed among reservoirs through time (Figure 2; repeated measures ANOVA: 1993, reservoir, $F=5.5$, df $=2,25$; time, $F=2.8$, df $=5,25 ; P<0.05$ for both effects). A significant interaction between time and reservoir effects might have occurred because a disproportionately large number of largemouth bass were seined on one date in Hargus Lake, and CPE of largemouth bass increased during the season in Kokosing Lake (Figure 2; repeated measures ANOVA: time $\times$ reservoir interaction, $F=5.3$, df $=10,25, P<0.05$ ). In summary, relative abundances of largemouth bass were generally low and variable among reservoirs and years.

\section{Largemouth Bass Growth}

Patterns of largemouth bass growth within reservoirs differed across years. We categorized growth in reservoirs as either "slow" $(\leq 0.071$ g/d) or "fast" ( $\geq 0.121 \mathrm{~g} / \mathrm{d}$; Table 1). In 1993 and 1994, growth of largemouth bass in Hargus Lake increased substantially from slow in early summer to fast by early August (Figure 3A; Table 1; two-phase versus single regression: $1993, F=$ 51.1, df $=1,169 ; 1994, F=4.2$, df $=1,182$; $P<0.05$ for both tests). We could not quantify growth beyond early August 1992 because no largemouth bass were captured. Hence, a single regression adequately modeled slow growth during June through August 1992 (Figure 3A; twophase versus single regression: $1992, F=2.5$, df $=1,61, P>0.05)$, which was similar in magnitude to other years (Figure 3A; Table 1). In Kokosing Lake during 1992 and 1993, largemouth bass grew slowly during early summer; 95\% confidence intervals for mean growth rates overlapped zero by late summer (Figure 3B; Table 1; two-phase versus single regression: $1992, F=$ 6.0 , df $=1,131 ; 1993, F=3.9$, df $=1,126 ; P$ $<0.05$ for both tests). Conversely, Kokosing largemouth bass grew rapidly throughout the season in 1994 (Table 1) with no apparent shift in growth rates (Figure 3B; Table 1; two-phase versus single regression: $1994, F=1.4$, df $=1,140$, 


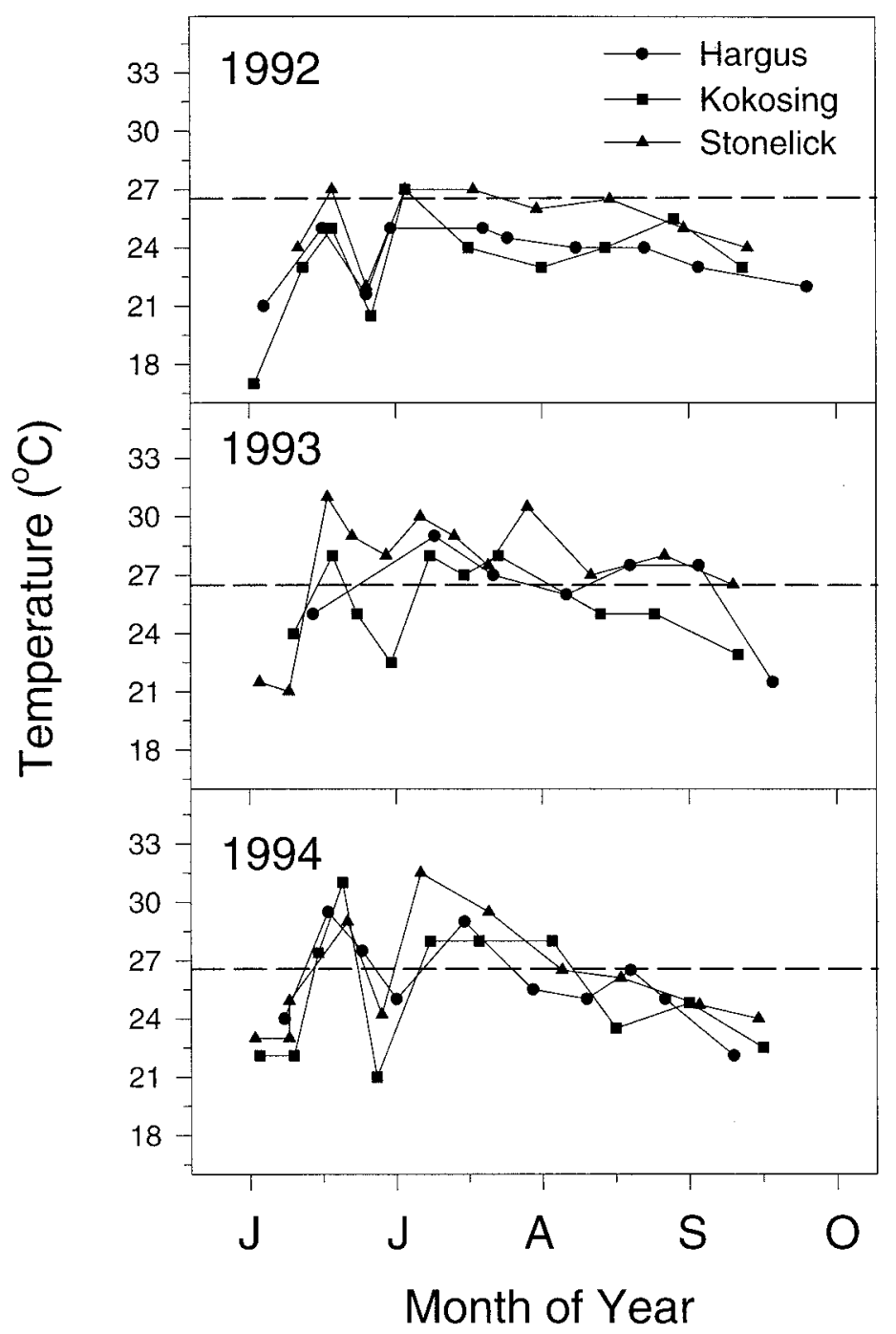

Figure 1.-Temperatures ( $0.5 \mathrm{~m}$ depth) quantified at dam sites on each sampling date during June through midSeptember 1992-1994 in Hargus, Kokosing, and Stonelick lakes, Ohio. Dashed lines indicate the optimal temperature for age-0 largemouth bass feeding at maximum rates (Hewett and Johnson 1992).

$P>0.05)$. Largemouth bass grew slowly but constantly in Stonelick Lake during 1992 and 1994; conversely, they grew rapidly with no shift in growth rate during 1993 (Figure 3C; Table 1; twophase versus single regression: $1992, F=1.5$, df $=1,14 ; 1993, F=1.5$, df $=1,25 ; 1994, F=$ $1.3, \mathrm{df}=1,55 ; P>0.05$ for all tests). In summary, patterns of growth were fairly consistent in Hargus Lake with growth increasing rapidly by fall. Conversely, in both Kokosing Lake in 1994 and Stonelick Lake in 1993, largemouth bass grew about $200 \%$ faster relative to other years.
When growth among reservoirs was compared, growth rates differed for all but one of the pairwise comparisons (Figure 3A-C; Table 2; $t$-tests for slopes). Before the second growth phase (generally before mid-August) during all 3 years, largemouth bass grew slowly in Hargus Lake relative to Kokosing and Stonelick lakes (Figure 3A-C; Table 2 ; $t$-tests of slopes). Relative differences in largemouth bass growth between Kokosing and Stonelick lakes varied across years during this time (Figure 3A-C; Table 2; $t$-tests of slopes). In contrast, after mid-August, Hargus largemouth bass consistently grew more rapidly than largemouth bass in 


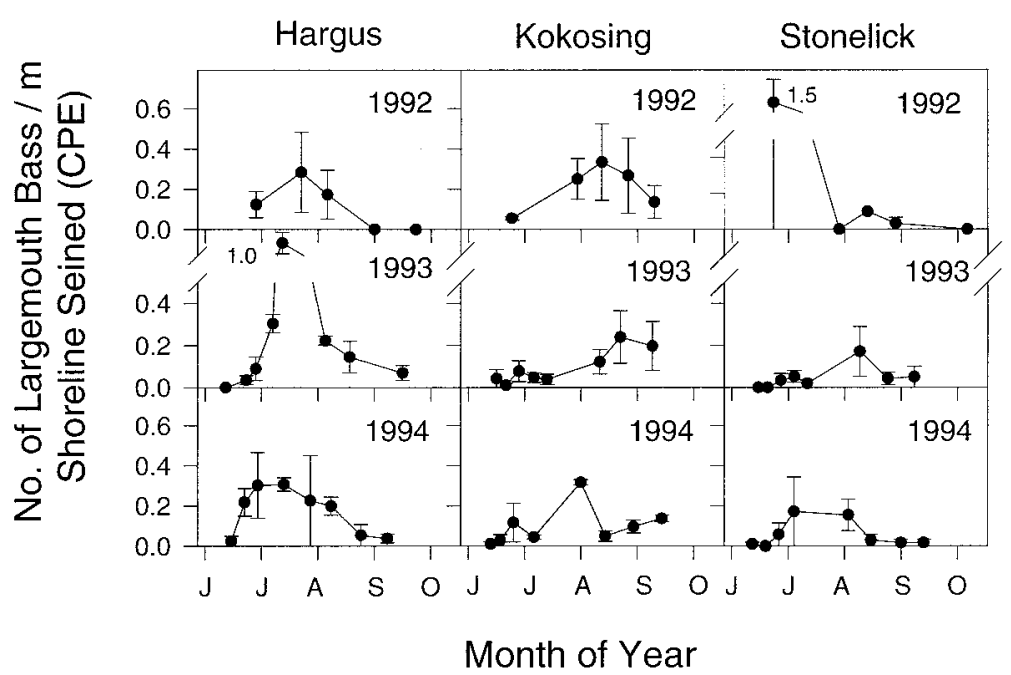

FIGURE 2.-Mean \pm SE number of age-0 largemouth bass per meter of shoreline $(N=3$ seine transects per reservoir per weekly sampling date) in three Ohio reservoirs during June-October 1992-1994.

either Kokosing or Stonelick lakes (Figure 3A-C; Table 2; $t$-tests of slopes). After mid-August in Kokosing Lake during all years, largemouth bass grew more slowly than those in other reservoirs (Figure 3A-C; Table 2; $t$-tests of slopes).

Differences in growth rates among reservoirs did not necessarily translate to predictable sizes of largemouth bass by fall. Growth rates of largemouth bass in other reservoirs often exceeded or matched those of constantly growing largemouth bass in Stonelick Lake during a portion of each year (Figure 3A-C; Table 2). However, except during 1994 when rapidly growing Kokosing largemouth bass were largest by fall, sizes of Stonelick largemouth bass exceeded those in Hargus and Kokosing reservoirs (Table 3 ; $t$-tests for sizes). Interestingly, these fall size differences had manifested themselves by early summer. Stonelick largemouth bass (mean grams wet weight \pm SD for 1992, 1993, and 1994: $2.7 \pm 1.2,2.1 \pm 4.0$,

TABLE 1.-Mean growth rates $\left(b_{1}, \mathrm{~g} / \mathrm{d}\right)$ and intercepts $\left(b_{0}\right) \pm 95 \%$ confidence intervals from single or continuous two-phase linear regressions for the independent variable time versus the dependent variable wet weight $\left(y=b_{1} x+\right.$ $b_{0}$ ) of largemouth bass in three Ohio reservoirs $(N=$ number of fish). If two-phase regression models did not reduce residual sum of squares relative to single regressions ( $F$-test, $P>0.05$ ), we concluded that growth rates for the first growth phase adequately described growth during the entire season; hence, growth rates were not estimated with a second regression (termed NA, not applicable). Except for the second growth phases for Kokosing Lake in 1992 and 1993 when mean growth rates overlapped zero, all regression models were significant $(F$-tests, $P<0.05)$. See Figure $3 \mathrm{~A}-\mathrm{C}$ for growth in wet weight.

\begin{tabular}{|c|c|c|c|c|c|c|c|}
\hline \multirow[b]{2}{*}{ Year } & \multicolumn{3}{|c|}{ 1st growth phase } & \multicolumn{3}{|c|}{ 2nd growth phase } & \multirow{2}{*}{$\begin{array}{l}\text { Date of } \\
\text { growth } \\
\text { change }\end{array}$} \\
\hline & $b_{1}(\mathrm{~g} / \mathrm{d})$ & $b_{0}$ & $N$ & $b_{1}(\mathrm{~g} / \mathrm{d})$ & $b_{0}$ & $N$ & \\
\hline \multicolumn{8}{|c|}{ Hargus Lake } \\
\hline 1992 & $0.036 \pm 0.009$ & $-5.8 \pm 1.8$ & 65 & NA & NA & NA & NA \\
\hline 1993 & $0.032 \pm 0.013$ & $-4.9 \pm 2.7$ & 156 & $0.243 \pm 0.079$ & $-55 \pm 20$ & 16 & 19 Aug \\
\hline 1994 & $0.048 \pm 0.016$ & $-7.9 \pm 3.2$ & 117 & $0.154 \pm 0.053$ & $-35 \pm 15$ & 43 & 8 Sep \\
\hline \multicolumn{8}{|c|}{ Kokosing Lake } \\
\hline 1992 & $0.064 \pm 0.024$ & $-10 \pm 4.8$ & 82 & $-0.016 \pm 0.098$ & $7.6 \pm 24$ & 53 & $13 \mathrm{Aug}$ \\
\hline 1993 & $0.054 \pm 0.014$ & $-9.2 \pm 4.9$ & 79 & $0.013 \pm 0.058$ & $0.96 \pm 15$ & 51 & $23 \mathrm{Aug}$ \\
\hline 1994 & $0.121 \pm 0.034$ & $-21 \pm 7.2$ & 144 & NA & NA & NA & NA \\
\hline \multicolumn{8}{|c|}{ Stonelick Lake } \\
\hline 1992 & $0.052 \pm 0.023$ & $-7.1 \pm 5.6$ & 18 & NA & NA & NA & NA \\
\hline 1993 & $0.135 \pm 0.026$ & $-24 \pm 5.5$ & 29 & NA & NA & NA & NA \\
\hline 1994 & $0.071 \pm 0.009$ & $-11 \pm 2.0$ & 59 & NA & NA & NA & NA \\
\hline
\end{tabular}




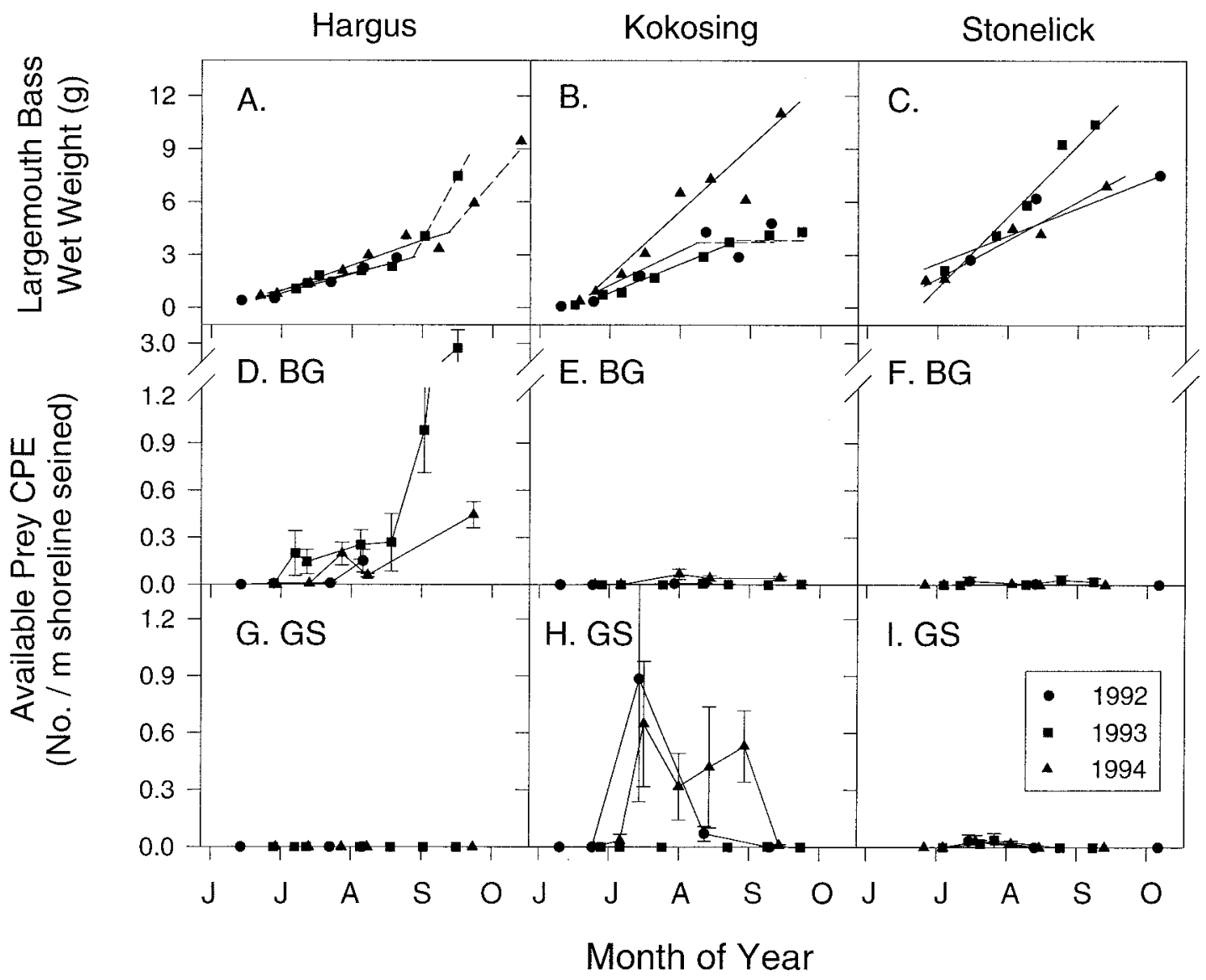

Figure 3.-(A-C) Mean wet weights (g; see Table 1 for sample sizes and growth rates) of age-0 largemouth bass at each sampling date during June-October 1992-1994 in (A) Hargus, (B) Kokosing, and (C) Stonelick lakes, Ohio. Across reservoirs, years, and dates, the median SE was $28 \%$ of the mean daily weight. Unbroken lines are predicted sizes of largemouth bass from the first growth phase of continuous two-phase regressions or from single regressions (Table 1). Broken lines are predicted sizes from the second growth phase of two-phase regressions, where applicable (Table 1). Except for the second-phase regressions for Kokosing Lake in 1992 and 1993, all regression models were significant ( $F$-tests, $P<0.05$; Table 1 ). (D-I) Mean $\pm \mathrm{SE} \mathrm{CPE} \mathrm{(number} \mathrm{of} \mathrm{fish} / \mathrm{m}$ of shoreline) of (D-F) bluegills (BG) and (G-I) gizzard shad (GS) available to and smaller than gape limits of largemouth bass on weekly sampling dates in Hargus, Kokosing, and Stonelick lakes, Ohio, during June-October 1992-1994 ( $N=3$ seine transects per reservoir on each date).

and $1.5 \pm 0.5$, respectively) were consistently larger than those in Hargus Lake (1992-1994: $1.4 \pm$ $0.9,1.1 \pm 0.5$, and $0.7 \pm 0.2 \mathrm{~g})$ and Kokosing Lake (1992-1994: $1.8 \pm 1.2,0.9 \pm 0.3$, and 0.9 $\pm 0.3 \mathrm{~g}$ ) across years (Figure 3; two-way ANOVA: Reservoir, $F=12.1$, df $=2,107$; Year, $F=10.8$, df $=2,107 ; P<0.05$ for both effects; reservoir $\times$ year, $F=0.7$, df $=4,107, P>0.05)$. Mean sizes of largemouth bass in reservoirs were ordered as Stonelick Lake $>$ Kokosing Lake $=$ Hargus Lake by late June-early July (Tukey's multiple comparisons, $P<0.05$ ).

\section{Available Prey Fishes}

Available prey fish abundances as estimated by CPE differed among reservoirs. By August 1993 and 1994, bluegill availability increased substantially through time in Hargus Lake relative to Kokosing and Stonelick lakes as indicated by significant reservoir and time effects (Figure 3D-F; repeated-measures ANOVA: 1993, reservoir, $F=$ 185.2, df $=2,5$; time, $F=6.8$, df $=7,30 ; 1994$, reservoir, $F=21.7$, df $=2,6$; time, $F=20.3$, df $=4,24 ; P<0.05$ for all effects in both tests) as well as significant time by reservoir interactions 
TABLE 2.-Results of two-tailed $t$-tests comparing growth rates $(\mathrm{g} / \mathrm{d})$ of largemouth bass each year between Hargus (H), Kokosing (K), and Stonelick (S) lakes, Ohio. Except for one pairwise comparison (denoted by $*$ ), $t$-tests with $\alpha$ adjusted for multiple comparisons were significant $(P<0.002)$. Relative magnitude of growth rates are compared with logical operators $(=,>$, or $<$ when comparisons were possible). If a second phase in growth did not occur for both lakes within a comparison or if insufficient largemouth bass were sampled (as for Hargus in 1992), a $t$-test was not applicable (NA). See Table 1 for regressions and Figure $3 \mathrm{~A}-\mathrm{C}$ for growth in wet weight.

\begin{tabular}{|c|c|c|c|}
\hline Year & $\begin{array}{l}\text { Reservoir } \\
\text { comparison }\end{array}$ & $t$ & df \\
\hline \multicolumn{4}{|c|}{ First growth phase (before mid-August) } \\
\hline 1992 & $\begin{array}{l}\mathrm{H}<\mathrm{K} \\
\mathrm{H}<\mathrm{S} \\
\mathrm{K}=\mathrm{S}\end{array}$ & $\begin{array}{c}19.3 \\
6.0 \\
4.0^{*}\end{array}$ & $\begin{array}{r}145 \\
81 \\
98\end{array}$ \\
\hline 1993 & $\begin{array}{l}\mathrm{H}<\mathrm{K} \\
\mathrm{H}<\mathrm{S} \\
\mathrm{K}<\mathrm{S}\end{array}$ & $\begin{array}{l}23.2 \\
42.0 \\
32.1\end{array}$ & $\begin{array}{l}233 \\
183 \\
106\end{array}$ \\
\hline 1994 & $\begin{array}{l}\mathrm{H}<\mathrm{K} \\
\mathrm{H}<\mathrm{S} \\
\mathrm{K}>\mathrm{S}\end{array}$ & $\begin{array}{l}46.2 \\
24.0 \\
32.9\end{array}$ & $\begin{array}{l}259 \\
174 \\
201\end{array}$ \\
\hline \multicolumn{4}{|c|}{ Second growth phase (after mid-August) } \\
\hline 1992 & $\begin{array}{c}\mathrm{HK} \\
\mathrm{HS} \\
\mathrm{K}<\mathrm{S}\end{array}$ & $\begin{array}{c}\text { NA } \\
\text { NA } \\
9.5\end{array}$ & $\begin{array}{r}\text { NA } \\
\text { NA } \\
69\end{array}$ \\
\hline 1993 & $\begin{array}{l}\mathrm{H}>\mathrm{K} \\
\mathrm{H}>\mathrm{S} \\
\mathrm{K}<\mathrm{S}\end{array}$ & $\begin{array}{l}21.6 \\
10.7 \\
26.0\end{array}$ & $\begin{array}{l}65 \\
43 \\
78\end{array}$ \\
\hline 1994 & $\begin{array}{c}H>K \\
H>S \\
K S\end{array}$ & $\begin{array}{r}7.5 \\
20.5 \\
\text { NA }\end{array}$ & $\begin{array}{l}185 \\
100 \\
\text { NA }\end{array}$ \\
\hline
\end{tabular}

(Figure 3D-F; repeated-measures ANOVA: 1993, time $\times$ reservoir interaction, $F=5.7$, df $=12$, $30 ; 1994$, time $\times$ reservoir interaction, $F=14.4$, df $=8,24 ; P<0.05$ for both tests). When availability was greatest in Hargus Lake, about $30 \%$ of the bluegills per seine haul were sufficiently small to be vulnerable to largemouth bass. During 1992, reservoirs did not differ in their relative abundances of available bluegills though bluegill avail- ability did increase slightly through time (Figure 3D-F; repeated-measures ANOVA: 1992, reservoir, $P>0.05$; time, $F=4.8$, df $=3,18 ; P<$ $0.05)$. As with our growth estimates, note that we did not capture largemouth bass while seining in Hargus Lake after the second week of August 1992 (Figure 3D). By fall, age-0 bluegills generally were $30-50 \mathrm{~mm}$ TL in all reservoirs.

Because age- 0 gizzard shad were not captured in Hargus Lake during 1992-1994 (Figure 3G), we did not include these data in our analysis. During 1992 and 1993 in Kokosing and Stonelick lakes, abundances of available gizzard shad were variable and did not differ (Figure 3H-I; repeatedmeasures ANOVA: 1992 and 1993, both reservoir and time, $P>0.05)$. During 1994 when largemouth bass grew rapidly in Kokosing Lake, gizzard shad were consistently more abundant through time than in Stonelick Lake (Figure 3HI; repeated-measures ANOVA; reservoir, $F=12.2$, df $=1,4, P<0.05$; time, $P>0.05)$. Except during 1994 in Kokosing Lake where, on average, 50\% of gizzard shad in seine hauls were vulnerable, generally less than $1 \%$ of gizzard shad were vulnerable to largemouth bass. By fall, age- 0 gizzard shad were 50-90 mm TL in Kokosing and Stonelick lakes.

\section{Largemouth Bass Diets}

In Hargus Lake, relative proportions (per mg wet weight) of zooplankton, macroinvertebrates, and fish in diets through time were generally consistent across years (Figure 4). Except during June 1994 when two largemouth bass consumed small age-1 bluegill, largemouth bass during June of each year in Hargus Lake consumed mostly zooplankton and macroinvertebrates (Figure 4) including cladocerans, copepods, and dipteran larvae. During mid-July through early August, largemouth bass fed on both macroinvertebrates such as odonates of the suborder Zygoptera and fish

TABLE 3.-Estimates (mean \pm SE) of wet weights (g) of largemouth bass on September 15 in Hargus (H), Kokosing (K), and Stonelick (S) lakes, Ohio, from single or continuous two-phase regressions models. Pairwise comparisons of these estimated mean sizes within each year were compared with two-tailed $t$-tests. All $t$-tests with $\alpha$ adjusted for multiple comparisons were significant $(t>17$ and $\mathrm{df}>43$ for all comparisons; $P<0.004)$. See Figure $3 \mathrm{~A}-\mathrm{C}$ for growth in wet weight.

\begin{tabular}{cccrc}
\hline & \multicolumn{2}{c}{ Largemouth bass wet weight $(\mathrm{g})$ for reservoir: } & \multicolumn{2}{c}{$\begin{array}{c}\text { Relative fish sizes } \\
\text { by reservoir }\end{array}$} \\
\cline { 2 - 4 } Year & Hargus Lake & Kokosing Lake & Stonelick Lake & $\mathrm{S}>\mathrm{K}$ \\
1992 & $\mathrm{a}$ & $3.4 \pm 0.78$ & $6.4 \pm 0.57$ & $\mathrm{~S}>\mathrm{H}>\mathrm{K}$ \\
1993 & $7.2 \pm 0.41$ & $4.2 \pm 0.95$ & $11.1 \pm 0.63$ & $\mathrm{~K}>\mathrm{S}>\mathrm{H}$ \\
\hline
\end{tabular}

a No largemouth bass were captured during late summer 1992 in this reservoir. 

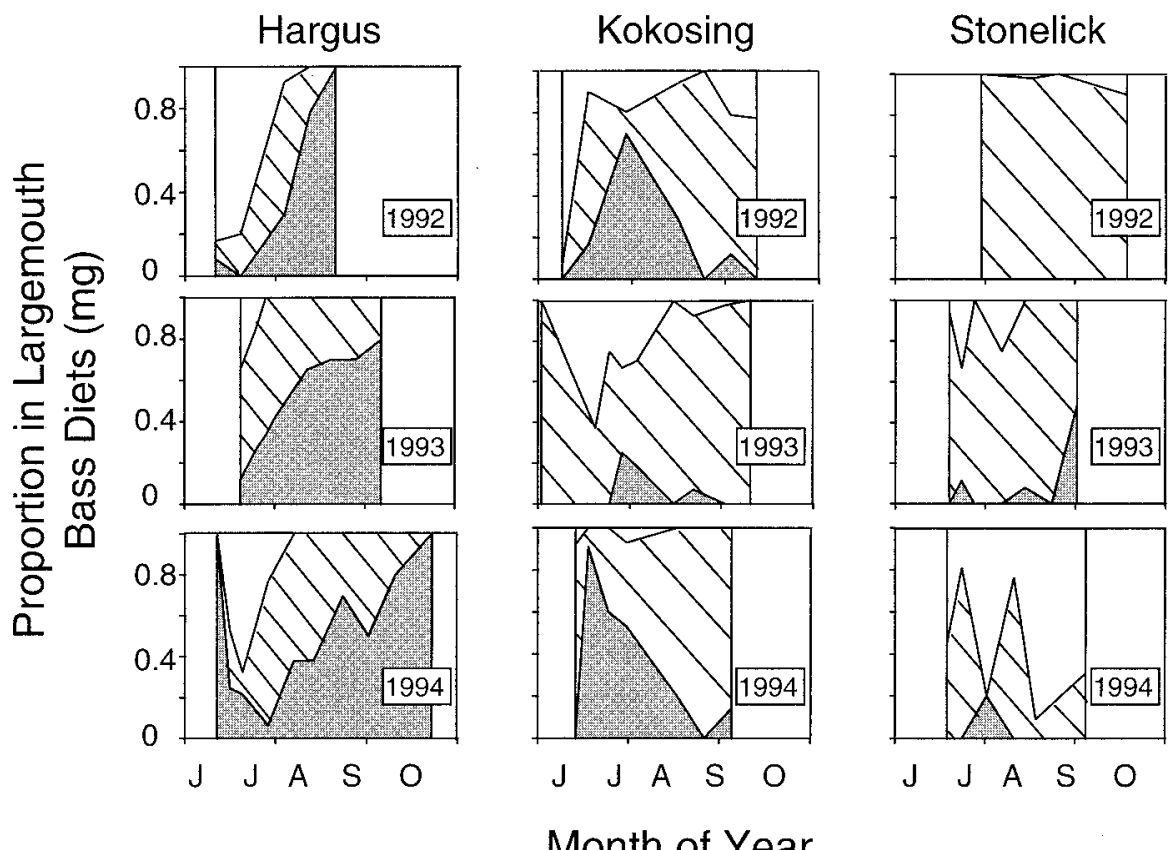

\section{Month of Year}

FIGURE 4.- Mean proportions (based on milligrams wet weight) of fish (filled), macroinvertebrates (hatched), and zooplankton (clear) in diets of age-0 largemouth bass ( $N \geq 4$ largemouth bass/reservoir for $74 \%$ of dates) in Hargus, Kokosing, and Stonelick lakes, Ohio, during June-October 1992-1994. Error values are not included. Across reservoirs, years, dates, and items, the median SE was $37 \%$ of the mean proportion.

such as bluegills. By late summer, primarily bluegills were consumed (Figure 4).

Temporal patterns of diet composition in Kokosing and Stonelick lakes differed markedly from those in Hargus Lake. During spring 1992 and 1994 in Kokosing Lake, diets of largemouth bass contained relatively high proportions of fish (mostly gizzard shad) and macroinvertebrates (Figure 4). Later, largemouth bass consumed primarily macroinvertebrates and few fish or zooplankton (Figure 4). During 1993 in Kokosing Lake, fish (exclusively bluegills) were less abundant in diets of largemouth bass during spring and early summer (Figure 4). Regardless of year, zooplankters and macroinvertebrates consumed by largemouth bass in Kokosing Lake included copepods, corixids, and dipteran larvae. In Stonelick Lake, fish (exclusively bluegills) were slightly more abundant in largemouth bass diets during several dates in 1993 than in the other years (Figure 4). Through fall 1992 and 1993, macroinvertebrates such as corixids and dipteran larvae were most abundant in diets of largemouth bass; conversely, in fall 1994, largemouth bass diets fluctuated between zooplankton (e.g., Moina and Scapholeberis) and macroinvertebrates (Figure 4).

\section{Discussion}

Previous work in Ohio reservoirs with threadfin shad, gizzard shad, and bluegill prey (Bremigan et al. 1991; DeVries et al. 1991) as well as in other systems (see DeVries and Stein 1990 for review), led Stein et al. (1995) to predict that age-0 largemouth bass should grow more slowly in systems with gizzard shad than in those with abundant bluegill. In our survey of three reservoirs across 3 years, these original predictions were unsupported: gizzard shad presence in Kokosing and Stonelick lakes did not consistently reduce summer growth and fall sizes of largemouth bass relative to Hargus Lake, our bluegill-dominated system. Clearly, these predictions were overly simplistic. Both summer growth and fall sizes of largemouth bass probably were driven by complex processes including the timing of size-structured interactions with prey fish assemblages.

Largemouth bass growth increases upon the dietary switch from macroinvertebrates to fish (Timmons et al. 1980; Keast and Eadie 1985; Olson 1996) because of the relatively high energy content and biomass of fish (Keast and Eadie 1985). For age- 0 piscivores, including largemouth bass in our 
reservoirs, the timing of this switch is driven by their size relative to prey fish and then influences summer growth (Miller and Storck 1984; Adams and DeAngelis 1987; Wright 1993; Phillips et al. 1995; Olson 1996). Because size structure of prey in reservoirs varied as a function of which species of prey fish was dominant, prey availability to largemouth bass varied, thus influencing largemouth bass growth.

In Hargus Lake, abundant bluegills should foster rapid growth of largemouth bass. Indeed, growth rates of largemouth bass increased from about 0.04 to $0.2 \mathrm{~g} / \mathrm{d}$ between early and late summer, as the largemouth bass reached sufficient sizes to consume bluegills, results quite similar to those from Michigan lakes (increasing from about 0.04 to $0.11 \mathrm{~g} / \mathrm{d}$; Olson 1996). In Kokosing and Stonelick lakes, we predicted poor growth of largemouth bass relative to Hargus Lake fish. Surprisingly, growth rates of largemouth bass in these two reservoirs always exceeded those in Hargus Lake during early summer. Though largemouth bass growth in these reservoirs fell below that in Hargus Lake in late summer, these systems often produced the largest largemouth bass by fall. To account for these differences, we must review patterns of growth among reservoirs and years.

Growth of largemouth bass in our gizzard-shaddominated reservoirs was either consistently slow or consistently fast. During years of consistently slow growth in Kokosing Lake $(1992,1993)$ and Stonelick Lake (1992, 1994), growth rates were slower than those of piscivorous largemouth bass during late summer in Hargus Lake (also see Olson 1996). However, growth rates in Kokosing Lake always exceeded those in Hargus Lake during early summer, due, in part, to a diet of fish. Even though age-0 largemouth bass were piscivorous during this time, their growth rates were still lower than expected. In 1992, largemouth bass in Kokosing Lake might have grown slower because maximum scope for growth occurs at $26.5^{\circ} \mathrm{C}$ (Hewett and Johnson 1992) and the lake reached this temperature only once during sampling. In 1993, fish were quite infrequent in diets of Kokosing largemouth bass, thus, probably contributing only moderately to growth despite warmer early summer temperatures. As in other studies wherein prey fish declined in abundance or grew to invulnerable sizes (Miller and Storck 1984; Phillips et al. 1995) or low temperatures slowed growth during the onset of piscivory (Buijse and Houthuijzen 1992), this moderate early growth in Kokosing largemouth bass decelerated by late summer as gizzard shad availability declined and fish disappeared from largemouth bass diets.

During slow-growth years in Stonelick Lake (1992, 1994), largemouth bass grew through the summer at rates similar to those in Kokosing Lake without consuming fish. Because low-intermediate densities of vegetation can increase the availability of both fish and nonfish prey (Crowder and Cooper 1982; Savino and Stein 1982; Bettoli et al. 1992; Brown and Lodge 1993), largemouth bass might have foraged quite successfully on macroinvertebrates in the moderately vegetated littoral zone of Stonelick Lake, as compared with the extremely sparse and extremely dense vegetation of Kokosing and Hargus lakes, respectively. Even though Stonelick largemouth bass grew slowly during these years, they always were largest by fall. Moderate, early summer growth might have contributed to large fall sizes. However, largemouth bass in Stonelick Lake were already $0.5-1.0 \mathrm{~g}$ larger than Hargus or Kokosing largemouth bass by our first sampling date. The relatively faster warming in Stonelick Lake, our most southern reservoir, during early spring might have led to earlier hatch dates (Summerfelt 1975; Carlander 1977; Goodgame and Miranda 1993), which, coupled with fast larval growth, then led to large sizes by early summer (Goodgame and Miranda 1993; Phillips et al. 1995).

During years of consistently rapid growth in Kokosing Lake (1994) and Stonelick Lake (1993), largemouth bass grew at rates similar to those of late-summer, piscivorous largemouth bass in Hargus Lake. Indeed, piscivory probably contributed to these growth patterns. During early summer 1994 in Kokosing Lake, largemouth bass consumed mostly gizzard shad, which were highly available relative to 1992 and 1993. Though fish declined in largemouth bass diets by August 1994 as they had in 1992, gizzard shad remained vulnerable during June through mid-September due to their relatively late appearance in spring and small sizes through the summer (Garvey 1997). Perhaps local patterns of spring warming or flooding influenced gizzard shad hatch times, growth, and survival that year (Michaletz 1997a). In addition, warm temperatures in 1994 in Kokosing Lake overlapped the temperature for optimum growth relatively often (Hewett and Johnson 1992), potentially facilitating growth. Though available prey fish were never abundant in Stonelick, bluegills appeared in largemouth bass diets on several dates during summer 1993, suggesting that fish prey, abundant macroinvertebrates, and 
warm summer temperatures combined to support rapid growth.

In summary, summer growth in Hargus Lake varied little among years: available age-0 bluegills only appeared and contributed to rapid growth by late summer, resulting in relatively small sizes of largemouth bass by fall. Conversely, patterns of growth in gizzard-shad-dominated systems varied among years and reservoirs, as is characteristic of these systems (Michaletz 1997b). In early summer, the relatively early appearance (by about 1-3 weeks) of gizzard shad in Ohio reservoirs potentially contributed to rapid growth rates and large fall sizes of largemouth bass. However, this event was rare, occurring during only 1 year in one reservoir (Kokosing Lake), probably as late-hatched gizzard shad grew slowly and the relatively warm, early summer temperatures facilitated largemouth bass growth. Bluegills might have contributed to 1 year of rapid growth in Stonelick Lake, though mechanisms underlying this observed growth are poorly understood. Generally, years of rapid summer growth in these gizzard-shad-dominated systems were rare. More commonly, largemouth bass grew moderately because appropriate sizes of prey fish were not abundant.

Though much of the summer growth could be explained, it did not necessarily translate to predictable fall sizes. A consistent switch to piscivory and rapid late-summer growth translated to only moderate sizes by fall in Hargus Lake, often allowing these fish to only "catch up" with moderately growing largemouth bass in Kokosing Lake. In Stonelick Lake, where largemouth bass often maintained a size advantage throughout the summer apparently without consuming fish very frequently, factors influencing growth during the first few weeks of life might have already dictated the extent of growth by fall. Because large fall sizes are likely to improve largemouth bass recruitment to the second year of life (Adams et al. 1982; Gutreuter and Anderson 1985; Ludsin and DeVries 1997), this lack of resolution between summer growth and fall size compromises our ability to predict the potential impact of differing prey assemblages on largemouth bass recruitment to the adult stock.

\section{Management Implications}

Rather than attempting to predict absolute sizes of largemouth bass by fall, we recommend that these small reservoir systems be managed by predicting how growth rates vary as a function of the dominant prey fish assemblage. In the relatively invariant bluegill-dominated system, differences in life history schedules between largemouth bass and their bluegill prey at these northern latitudes may limit the absolute potential for growth by fall (see Modde and Scalet 1985 for a similar argument for adult largemouth bass and bluegills). Thus, these systems cannot be managed to expedite the switch to piscivory and the increase in first-summer growth of age-0 largemouth bass. Conversely, subtle differences in the timing of appearance and growth of gizzard shad may translate into different consequences for growth of age-0 largemouth bass (Michaletz 1997b). Because growth, production, and timing of appearance of gizzard shad may be linked to factors such as water level fluctuations (Michaletz 1997a) as well as system productivity and turbidity (Bremigan 1997), land-use improvement at the watershed scale to reduce factors such as phosphorus and turbidity will be necessary to consistently reduce sizes of these gizzard shad prey during early summer (Stein et al. 1996). In addition, characteristics of largemouth bass populations may be managed to increase the likelihood of early piscivory and rapid growth. Because large adult largemouth bass may spawn earlier than small counterparts, increasing individual fish size within the adult stock (e.g., through size limits) can produce early hatched age-0 largemouth bass that are large enough to switch to gizzard shad in spring (Goodgame and Miranda 1993). Facilitating early piscivory could increase fall sizes of largemouth bass each year while simultaneously reducing the interannual variability in growth apparently inherent to systems with gizzard shad. By reducing variability, managers should be better able to predict the potential for largemouth bass growth each year, and from this, infer the likelihood of recruitment success.

\section{Acknowledgments}

We extend many thanks to N. Dingledine, $\mathrm{H}$. Thomas, N. Donovan, J. Eckert, B. Thompson, P. Edersheim, J. Dujnic, S. Strong Betz, M. Puleo, and D. Lozier for their efforts in the field and laboratory. Comments by P. Curtis, D. DeVries, E. Marschall, D. Stouder, and three anonymous reviewers on an earlier draft greatly improved this manuscript. Conceptual and analytical insight were provided by R. Wright and E. Marschall. This research was funded by National Science Foundation grants DEB 9407859 and DEB 9107173 to R.A.S. and by Federal Aid in Sport Fish Restoration Project F-69-P, administered jointly by the U.S. Fish and Wildlife Service and the Ohio Di- 
vision of Wildlife. A Presidential Fellowship from The Ohio State University supported J.E.G. during part of this work.

\section{References}

Adams, S. M., and D. L. DeAngelis. 1987. Indirect effects of early bass-shad interactions on predator population structure and food-web dynamics. Pages 103-117 in W. C. Kerfoot and A. Sih, editors. Predation: direct and indirect impacts on aquatic communities. University Press of New England, Hanover, New Hampshire.

Adams, S. M., R. B. McLean, and M. M. Huffman 1982. Structuring of a predator population through temperature-mediated effects on prey availability. Canadian Journal of Fisheries and Aquatic Sciences 39:1175-1184.

Bettoli, P. W., M. J. Maceina, R. L. Noble, and R. K. Betsill. 1992. Piscivory in largemouth bass as a function of aquatic vegetation abundance. North American Journal of Fisheries Mangement 12:509_ 516.

Bettoli, P., M. J. Maceina, R. L. Noble, and R. K. Betsill 1993. Response of a reservoir fish community to aquatic vegetation removal. North American Journal of Fisheries Management 13:110-124.

Bremigan, M. T. 1997. Variable recruitment of gizzard shad, a strong interactor in reservoirs: exploring causal mechanisms and implications for food webs. Doctoral dissertation. Ohio State University, Columbus.

Bremigan, M. T., E. M. Lewis, M. B. Jones, R. A. Stein, and D. R. DeVries. 1991. Evaluating the effects of stocking threadfin shad on young-of-year crappie, bluegill, and largemouth bass in Ohio lakes. Ohio Department of Natural Resources, Federal Aid in Sport Fish Restoration, F-57-R-13, Final Report, Columbus.

Bremigan, M. T., and R. A. Stein. 1994. Predator gape and zooplankton size: exploring a size-dependent recruitment mechanism in fishes. Canadian Journal of Fisheries and Aquatic Sciences 51:913-922.

Bremigan, M. T., and R. A. Stein. 1997. Experimental assessment of the influence of zooplankton size and density on gizzard shad recruitment. Transactions of the American Fisheries Society 126:622-637.

Brooks, J. L., and S. I. Dodson. 1965. Predation, body size, and composition of plankton. Science 15:2835.

Brown, K. M., and D. M. Lodge. 1993. Gastropods are actually less abundant in vegetated habitats: the importance of specifying null models. Limnology and Oceanography 38:217-225.

Buijse, A. D., and R. P. Houthuijzen. 1992. Piscivory, growth, and size-selective mortality of age-0 pikeperch (Stizostedion lucioperca). Canadian Journal of Fisheries and Aquatic Sciences 49:894-902.

Carlander, K. D. 1977. Handbook of freshwater fishery biology, volume 2. Iowa State University Press, Ames.

Carpenter, S. R., and seven coauthors. 1987. Regulation of lake primary productivity by food web structure. Ecology 68:1863-1876.

Cerri, R. D., and D. F. Fraser. 1983. Predation and risk in foraging minnows: balancing conflicting demands. American Naturalist 121:552-561.

Confer, J. L., and G. L. Lake. 1987. Influence of prey type on growth of young yellow perch (Perca flavescens). Canadian Journal of Fisheries and Aquatic Sciences 44:2028-2033.

Crowder, L. B., and W. E. Cooper. 1982. Habitat structural complexity and the interaction between bluegills and their prey. Ecology 63:1802-1813.

Culver, D. A., M. M. Boucherle, D. J. Bean, and J. W. Fletcher. 1985. Biomass of freshwater crustacean zooplankton from length-weight regressions. Canadian Journal of Fisheries and Aquatic Sciences 42:1380-1390.

Dettmers, J. M., and R. A. Stein. 1992. Food consumption by larval gizzard shad: zooplankton effects and implications for reservoir communities. Transactions of the American Fisheries Society 121: 494-507.

Dettmers, J. M., and R. A. Stein. 1996. Quantifying linkages among gizzard shad, zooplankton, and phytoplankton in reservoirs. Transactions of the American Fisheries Society 125:27-41.

DeVries, D. R., and R. A. Stein. 1990. Manipulating shad to enhance sport fisheries in North America: an assessment. North American Journal of Fisheries Management 10:209-223.

DeVries, D. R., and R. A. Stein. 1992. Complex interactions between fish and zooplankton: quantifying the role of an open-water planktivore. Canadian Journal of Fisheries and Aquatic Sciences 49:12121227.

DeVries, D. R., R. A. Stein, J. G. Miner, and G. G. Mittelbach. 1991. Stocking threadfin shad: consequences for young-of-year fishes. Transactions of the American Fisheries Society 120:368-381.

Dillard, J. G., and G. D. Novinger. 1975. Stocking largemouth bass in small impoundments. Pages 459-474 in H. Clepper, editor. Black bass biology and management. Sport Fishing Institute, Washington D.C.

Dumont, H. J., I. Van de Velde, and S. Dumont. 1975. The dry weight estimates of biomass in selection of Cladocera, Copepoda and Rotifera from the plankton, periphyton, and benthos of continental waters. Oecologia 19:75-97.

Garvey, J. E. 1997. Strong interactors and community structure: testing predictions for reservoir food webs. Doctoral dissertation. Ohio State University, Columbus.

Garvey, J. E., N. A. Dingledine, N. S. Donovan, and R. A. Stein. 1998. Exploring spatial and temporal variation within reservoir food webs: predictions for fish assemblages. Ecological Applications 8:104120.

Goodgame, L. S., and L. E. Miranda. 1993. Early growth and survival of age-0 largemouth bass in relation to parental size and swim-up time. Trans- 
actions of the American Fisheries Society 122:131138.

Grinstead, B. G., R. M. Gennings, G. R. Hooper, C. A. Schultz, and D. A. Whorton. 1978. Estimation of standing crop of fishes in the predator-stockingevaluation of reservoirs. Proceedings of the Annual Conference Southeastern Association of Fish and Wildlife Agencies 30(1976):120-130.

Guest, W. C., R. W. Drenner, S. T. Threlkeld, F. D. Martin, and J. D. Smith. 1990. Effects of gizzard shad and threadfin shad on zooplankton and young-ofyear white crappie production. Transactions of the American Fisheries Society 119:529-536.

Gutreuter, S. J., and R. O. Anderson. 1985. Importance of body size to the recruitment process in largemouth bass. Transactions of the American Fisheries Society $114: 317-327$.

Hambright, K. D., R. W. Drenner, S. R. McComas, and N. G. Hairston, Jr. 1991. Gape-limited piscivores, planktivore size refuges, and the trophic cascade hypothesis. Archiv für Hydrobiologie 121:389404.

Hewett, S. W., and B. L. Johnson. 1992. Fish bioenergetics model 2. University of Wisconsin, Sea Grant Institute, Technical Report WIS-SG-92-250, Madison.

Holland-Bartels, L. E., S. K. Littlejohn, and M. L. Huston. 1990. A guide to the larval fishes of the upper Mississippi River. U.S. Fish and Wildlife Service Publication, LaCrosse, Wisconsin.

Hoyle, J. A., and A. Keast. 1987. The effect of prey morphology and size on handling time in a piscivore, the largemouth bass (Micropterus salmoides). Canadian Journal of Zoology 65:1972-1977.

Hrbacek, J., M. Dvorakova, V. Korinek, and L. Prochazkova. 1961. Demonstration of the effect of fish stock on the species composition of zooplankton and the intensity of metabolism of the whole plankton assemblage. Internationale Vereinigung für Theoretische und Angewandte Limnologie Verhandlungen 14:192-195.

Jenkins, R. M. 1957. The effect of gizzard shad on the fish population of a small Oklahoma lake. Transactions of the American Fisheries Society 85:5874.

Johnson, B. M., R. A. Stein, and R. F. Carline. 1988. Use of a quadrat rotenone technique and bioenergetics modeling to evaluate prey availability to stocked piscivores. Transactions of the American Fisheries Society 117:127-141.

Keast, A., and J. McA. Eadie. 1985. Growth depensation in year-0 largemouth bass: the influence of diet. Transactions of the American Fisheries Society 114:204-213.

Kirk, J. P., W. D. Davies, and K. Park. 1986. Response of some members of the fish community to gizzard shad removal from Chambers County Public Fishing Lake, Alabama. North American Journal of Fisheries Management 6:252-255.

Lemly, A. D., and J. F. Dimmick. 1982. Growth of young-of-the-year and yearling centrarchids in re- lation to zooplankton in the littoral zone of lakes. Copeia 1982:305-321.

Ludsin, S. A., and D. R. DeVries. 1997. First-year recruitment of largemouth bass: the inter-dependency of early life stages. Ecological Applications 7: 1024-1038.

Michaletz, P. H. 1997a. Factors affecting abundance, growth, and survival of age- 0 gizzard shad. Transactions of the American Fisheries Society 126:84100.

Michaletz, P. H. 1997b. Influence of abundance and size of age- 0 gizzard shad on predator diets, diet overlap, and growth. Transactions of the American Fisheries Society $126: 101-111$.

Miller, S. J., and T. Storck. 1984. Temporal spawning distribution of largemouth bass and young-of-year growth, determined from daily otolith rings. Transactions of the American Fisheries Society 113:571578.

Mills, E. L., M. V. Pol, R. E. Sherman, and T. B. Culver. 1989. Inter-relationships between prey body size and growth of age-0 yellow perch. Transactions of the American Fisheries Society 118:1-10.

Miranda, L. E., and W. D. Hubbard. 1994a. Lengthdependent winter survival and lipid composition of age-0 largemouth bass in Bay Springs Reservoir, Mississippi. Transactions of the American Fisheries Society 123:80-87.

Miranda, L. E., and W. D. Hubbard. 1994b. Winter survival of age-0 largemouth bass relative to size, predators and shelter. North American Journal of Fisheries Management 14:790-796.

Mittelbach, G. G., A. M. Turner, D. J. Hall, J. E. Rettig, and C. W. Osenberg. 1995. Perturbation and resilience: a long-term, whole-lake study of predator extinction and reintroduction. Ecology 76:23472360.

Modde, T., and C. G. Scalet. 1985. Latitudinal growth effects on predator-prey interactions between largemouth bass and bluegill in ponds. North American Journal of Fisheries Management 5:227-232.

Neter, J., W. Wasserman, and M. H. Kutner. 1990. Applied linear statistical models: regression, analysis of variance, and experimental designs. Irwin, Boston.

Nickerson, D. M., D. E. Facey, and G. D. Grossman. 1989. Estimating physiological thresholds with continuous two-phase regression. Physiological Zoology 62:866-887.

Niimi, A. J., and F. W. H. Beamish. 1974. Bioenergetics and growth of largemouth bass (Micropterus salmoides) in relation to body weight and temperature. Canadian Journal of Zoology 52:447-456.

Noble, R. L. 1975. Growth of young yellow perch (Perca flavescens) in relation to zooplankton populations. Transactions of the American Fisheries Society 104:731-743.

Noble, R. L. 1981. Management of forage fishes in impoundments of the southern United States. Transactions of the American Fisheries Society 110:738750.

Olmstead, L. L. 1974. The ecology of largemouth bass 
(Micropterus salmoides) and spotted bass (Micropterus punctulatus) in Lake Fort Smith, Arkansas. Doctoral dissertation. University of Arkansas, Little Rock.

Olson, M. H. 1996. Ontogenetic niche shifts in largemouth bass: variability and consequences for firstyear growth. Ecology 77:179-190.

Paine, R. T. 1966. Food web complexity and species diversity. American Naturalist 100:65-75.

Phillips, J. M., J. R. Jackson, and R. L. Noble. 1995. Hatching date influence on age-specific diet and growth of age-0 largemouth bass. Transactions of the American Fisheries Society 124:370-379.

Ploskey, G. R., and R. M. Jenkins. 1982. Biomass model of reservoir fish and fish-food interactions, with implications for management. North American Journal of Fisheries Management 2:105-121.

Power, M. E. 1990. Effects of fish in river food webs. Science 250:811-814.

Rice, J. A., and P. A. Cochran. 1984. Independent evaluation of a bioenergetics model for largemouth bass. Ecology 65:732-739.

SAS Institute. 1983. SAS users guide: statistics, version 5 edition. SAS Institute, Cary, North Carolina. USA.

Savino, J. F., and R. A. Stein. 1982. Predator-prey interaction between largemouth bass and bluegillls as influenced by simulated, submersed vegetation. Transactions of the American Fisheries Society 111: 255-266.

Smock, L. A. 1980. Relationships between body size and biomass of aquatic insects. Freshwater Biology 10:375-383

Sokal, R. R., and F. J. Rohlf. 1981. Biometry: the principles and practice of statistics in biological research. Freeman, New York.

Stein, R. A., M. T. Bremigan, and J. M. Dettmers. 1996. Understanding reservoir systems with experimental tests of ecological theory: a prescription for management. Pages 12-22 in L. E. Miranda and D. R.
DeVries, editors. Multidimensional approaches to reservoir fisheries management. American Fisheries Society, Symposium 16, Bethesda, Maryland.

Stein, R. A., D. R. DeVries, and J. M. Dettmers. 1995. Food web regulation by a planktivore: exploring the generality of the trophic cascade hypothesis. Canadian Journal of Fisheries and Aquatic Sciences $52: 2518-2526$.

Storck, T. W. 1986. Importance of gizzard shad in the diet of largemouth bass in Lake Shelbyville, Illinois. Transactions of the American Fisheries Society 115: $21-27$.

Summerfelt, R. C. 1975. Relationship between weather and year-class strength of largemouth bass. Pages 166-174 in H. Clepper, editor. Black bass biology and management. Sport Fishing Institute, Washington, D.C.

Swingle, H. S., and E. V. Smith. 1940. Experiments on the stocking of fish ponds. Transactions of the North American Wildlife Conference 5:267-276.

Timmons, T. J., W. L. Shelton, and W. D. Davies. 1980. Differential growth of largemouth bass in West Point Reservoir, Alabama-Georgia. Transactions of the American Fisheries Society 109:176-186.

Wahl, D. H., and R. A. Stein. 1991. Food consumption and growth of three esocids: field tests of a bioenergetics model. Transactions of the American Fisheries Society 120:230-246.

Wright, R. A. 1993. Size dependence of growth, consumption and survival in juvenile largemouth bass: combining experimental manipulation and individual-based simulation. Doctoral dissertation. University of Wisconsin, Madison.

Ziebell, C. D., J. C. Tash, and R. L. Barefield. 1986. Impact of threadfin shad on macrocrustacean zooplankton in two Arizona lakes. Journal of Freshwater Ecology 3:399-406.

Received October 4, 1996 Accepted July 28, 1997 